\title{
Improvement of 2-Vessel Occlusion Cerebral Ischaemia/Reperfusion-Induced Corticostriatal Electrolyte and Redox Imbalance, Lactic Acidosis and Modified Acetylcholinesterase Activity by Kolaviron Correlates with Reduction in Neurobehavioural Deficits
}

\author{
Afolabi Clement Akinmoladun ${ }^{a} \quad$ Ibrahim Olabayode Saliu ${ }^{a}$ \\ Boyede Dele Olowookere $^{\mathrm{a}} \quad$ Olubukola Benedicta Ojo ${ }^{\mathrm{a}} \quad$ Mary Tolulope Olaleye $^{\mathrm{a}}$ \\ Ebenezer Olatunde Farombi $^{\text {b }} \quad$ Afolabi Akintunde Akindahunsi $^{a}$ \\ a Biochemical Pharmacology and Toxicology Laboratories, Department of Biochemistry, The Federal University of \\ Technology, Akure, Nigeria; ${ }^{b}$ Drug Metabolism and Molecular Toxicology Unit, Department of Biochemistry, College of \\ Medicine, University of Ibadan, Ibadan, Nigeria
}

\section{Keywords}

Cerebral ischaemia $\cdot$ Kolaviron · Cation levels $\cdot$ Redox imbalance $\cdot$ Neurobehavioural effects $\cdot$ Stroke

\footnotetext{
Abstract

Background: Disruption of electrolyte, redox and neurochemical homeostasis alongside cellular energy crisis is a hallmark of cerebral ischaemia and reperfusion injury. Purpose: This study investigated the effect of kolaviron (KV) on cortical and striatal cation imbalance, oxidative stress and neurochemical disturbances as well as neurobehavioural deficits in animals subjected to bilateral common carotid artery occlusion (BCCAO)-induced ischaemia/reperfusion injury. Methods: KV was administered at a dose of 100 or 200 $\mathrm{mg} / \mathrm{kg}$ to male Wistar rats $1 \mathrm{~h}$ before a $30 \mathrm{~min} \mathrm{BCCAO} / 4 \mathrm{~h}$ reperfusion (I/R). This was followed by neurobehavioral assessment and biochemical evaluations of cation levels, oxidative stress indicators, lactate dehydrogenase activity and
}

(c) 2017 S. Karger AG, Basel

E-Mail karger@karger.com www.karger.com/aon acetylcholinesterase (AChE) activity in the brain of animals. Conclusion: $\mathrm{KV}$ significantly restored altered cortical and striatal $\mathrm{Ca}^{2+}, \mathrm{Na}^{+}, \mathrm{K}^{+}$and $\mathrm{Mg}^{2+}$ levels, ameliorated redox imbalance, lactic acidosis and modified AChE activity caused by I/R injury. The favourable neurobehavioural effects of KV correlated with biochemical outcomes. The pharmacological potential of KV in the treatment and management of ischemic stroke and allied pathological conditions via multiple targets (neurotransmitter metabolism, bioenergetic failure and ionic homeostasis) is highlighted by the study.

(c) 2017 S. Karger AG, Basel

\section{Introduction}

Ischemic stroke is a leading cause of death and severe disability and has become a burden on healthcare and social service resources in many countries [1-4]. There is still limited available drug treatment for stroke, and the state and 
extent of knowledge and treatment of ischemic brain injury is inadequate. Therefore, therapeutic strategies are being explored to improve functional outcome after stroke injury [5, 6]. Redox disequilibrium, disruption of ionic homeostasis, lactic acidosis and defects in neurotransmitter metabolism are critical aspects of cerebral ischaemia/reperfusion injury. They are associated with broader, well-defined events in stroke pathophysiology, such as excitotoxicity and inflammation, and present targets for neuroprotection [7-12].

Phytoextracts or their products have been reported to improve circulation to the brain, thereby protecting it against ischemic injury and neuronal death. This protection against cerebral ischaemia, and other reported pharmacological properties like antioxidant, neuroprotective and anti-inflammatory activities justify the intensive scientific investigation into their anti-stroke potential [13-16]. Kolaviron (KV) is the predominant bioactive constituent in Garcinia kola seed. It is a complex of biflavanones GB1, GB2 and kolaflavanone [17, 18]. Flavonoids have been proposed to play a useful role in protecting the central nervous system against oxidative and excitotoxic stress [19-22]. In particular, KV showed neuroprotection in several models of cerebral injury $[17,23,24]$. This work investigated the protective capability of acute KV pretreatment on cerebral ischaemia/reperfusion-induced brain dysfunction in rats.

\section{Materials and Methods}

\section{Chemicals}

Chloral hydrate, sodium azide, glutathione, Ellman's reagent (5,5'-dithiobis-2-nitrobenzoic acid or DTNB), adrenaline, tripyridyl triazine (TPTZ), and acetylcholine iodide were purchased from Sigma-Aldrich (St. Louis, MO, USA). All other chemicals and reagents used for this research were of analytical grade.

\section{Extraction of $K V$}

$\mathrm{KV}$ was isolated as per previously published procedure [25]. Briefly, the powdered seeds of Garcinia kola were extracted with light petroleum ether (boiling point $40-60^{\circ} \mathrm{C}$ ) in a soxhlet for $24 \mathrm{~h}$. The defatted dried marc was repacked and extracted with acetone. The extract was concentrated and diluted twice its volume with water and extracted with ethyl acetate $(6 \times 300$ $\mathrm{mL}$ ). The concentrated ethyl acetate yielded a golden yellow solid, KV (Fig. 1), which consists of Garcinia biflavonoid GB-1 ( $3^{\prime \prime}, 4^{\prime}, 4^{\prime \prime \prime}, 5,5^{\prime \prime}, 7,7^{\prime \prime}$-heptahydroxy-3, $8^{\prime \prime}$ biflavanone), GB-2 $\left(3^{\prime \prime}, 4^{\prime}, 4^{\prime \prime \prime}, 5,5^{\prime \prime}, 5^{\prime \prime \prime}, 7,7^{\prime \prime}\right.$-octa-hydroxy-3,8" -biflavanone), and kolaflavanone $\left(3^{\prime \prime}, 4^{\prime}, 4^{\prime \prime \prime}, 5,5^{\prime \prime}, 5^{\prime \prime \prime}, 7,7^{\prime \prime}\right.$ octahydroxy- $4^{\prime \prime \prime}$-methoxy$3,8^{\prime \prime}$-biflavanone).

\section{Animal Grouping and Treatment}

Male Wistar rats $(250 \pm 20 \mathrm{~g})$ bred and housed in the primate colony of the animal house of Department of Animal Production and Health, The Federal University of Technology, Akure, Nigeria,

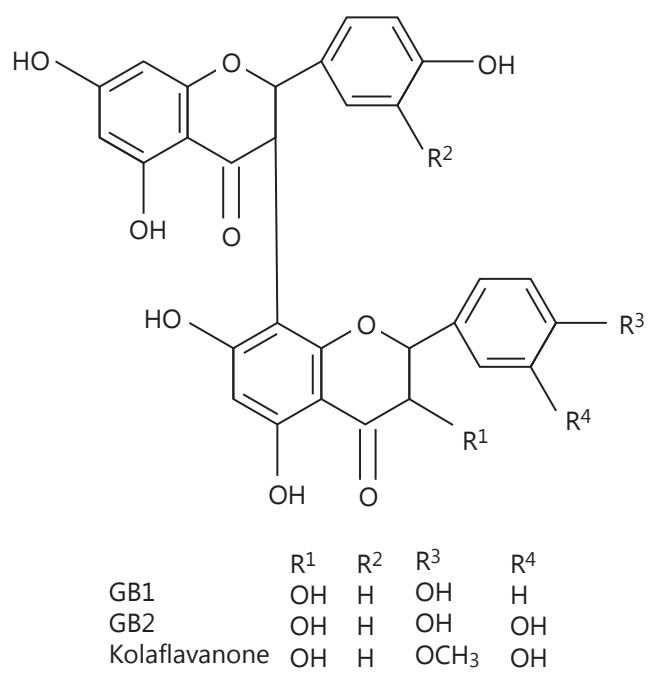

Fig. 1. Chemical structure of kolaviron.

were used for the study. The experiment was approved by a research Ethics Committee of the institution. Animals were fed rat chow and water ad lib and handled and used in accordance with the international guide for the care and use of laboratory animals (National Institute of Health, NIH publication No. 8023, 1978). All efforts were made to minimize animal suffering and to reduce the number of animals used.

Animals were divided into 8 groups. Group 1 (Sham) received vehicle only, without undergoing bilateral common carotid artery occlusion (BCCAO). Group 2 (ischemic/reperfusion control) received vehicle and was subjected to BCCAO for $30 \mathrm{~min}$ followed by $4 \mathrm{~h}$ of reperfusion (I/R). Groups 3 and 4 were orally administered 100 and $200 \mathrm{mg} / \mathrm{kg} \mathrm{KV}$, respectively, 30 min before I/R, while group 5 (reference group) received $20 \mathrm{mg} / \mathrm{kg}$ quercetin, i.p., $30 \mathrm{~min}$ before I/R. Groups 6, 7 and 8 received $100 \mathrm{mg} / \mathrm{kg} \mathrm{KV,} 200 \mathrm{mg} / \mathrm{kg}$ $\mathrm{KV}$ and quercetin, respectively, without I/R.

\section{Experimental Procedure for BCCAO and Reperfusion}

BCCAO, a 2-vessel occlusion model of global cerebral ischaemia, was performed according to the method of Farbiszewski et al. [26] making slight modifications. Rats were anaesthetized with chloral hydrate $(350 \mathrm{mg} / \mathrm{kg}$, i.p.) and placed in a supine position. A midline incision was made in the neck region. Both right and left common carotid arteries were located between the sternomastoid and sternohyoid muscles and carefully separated from adjoining nerves and vessels. A cotton thread was passed below each carotid artery and used to ligate the arteries for $30 \mathrm{~min}$ to induce ischaemia. After $30 \mathrm{~min}$ of cerebral ischaemia, the threads were removed from both arteries to allow the reflow of blood through carotid arteries (reperfusion) for $4 \mathrm{~h}$. The incision was sutured back and the sutured area was cleaned with $70 \%$ ethanol and sprayed with an antiseptic powder. While performing the surgical procedure, the body temperature was maintained at $37^{\circ} \mathrm{C} \pm 1^{\circ} \mathrm{C}$ with the help of a heating lamp. Sham animals received the same surgical procedures except that the common carotid arteries were not occluded. After the period of reperfusion, when animals had 
regained consciousness from anaesthesia, neurobehavioural performance was assessed. Thereafter, animals were sacrificed by cervical dislocation and brains dissected. The cortex and striatum were separated and processed for biochemical estimations.

\section{Assessment of Neurological Deficits}

Neurobehavioural assessment was carried out to test motor and cognitive performance. Initiation of walking test to assess motor coordination and turning in the alley test, which assessed both motor and cognitive functions, was performed as described by Sunil et al. [21]. For the initiation of walking test, the experimental animal was placed on a flat surface and the time taken (in seconds) for the animal to move a distance equal to its body length is recorded. For the turning in an alley test, rats were placed facing the back wall of an alley ( $5 \mathrm{~cm}$ wide and $25 \mathrm{~cm}$ high). The duration of time required for the animals to turn around and face an open end of the alley was recorded. The beam balance test, which evaluates the efficiency of a rat to balance on an elevated $120-\mathrm{cm}$ long beam ( $2.3 \mathrm{~cm}$ diameter, $50 \mathrm{~cm}$ above the floor), was carried out according to the method described by Alexis et al. [27]. Rats were perpendicularly positioned at the centre of the beam and maintained for a maximum of $60 \mathrm{~s}$. Performance of animals was assessed with a score, which ranged from 0 to $6(0=$ balances with steady posture, 1 = grasp side of the beam, 2 = hugs the beam and one limb falls down from the beam, 3 = hugs the beam and 2 limbs fall down from the beam or spin on the beam, $4=$ attempts to balance on the beam but falls off in less than $40 \mathrm{~s}, 5=$ attempts to balance on the beam but falls off in less than $20 \mathrm{~s}, 6=$ falls off with no attempt to balance or hang on to the beam in less than $20 \mathrm{~s}$ ).

\section{Biochemical Estimations}

Brains of sacrificed rats were excised and washed in ice cold $1.15 \%$ potassium chloride and blotted with filter paper. The cortex and striatum were removed and separately homogenized in phosphate-buffered saline ( $\mathrm{pH} 7.4$ ) using a Teflon homogenizer to prepare $10 \%$ homogenates. The resulting homogenates were centrifuged separately at $10,000 \mathrm{~g}$ at $4^{\circ} \mathrm{C}$ for $10 \mathrm{~min}$ to obtain the supernatants, which were used for biochemical analyses.

\section{Measurement of Oxidative Stress Markers}

Reduced glutathione (GSH) level was estimated from the yellow colour produced after reaction with DTNB using the method described by Beutler et al. [28]. Thiobarbituric acid reactive substances, products of lipid peroxidation, were evaluated as malondialdehyde (MDA) equivalent using the method described by Ohkawa et al. [29]. Glutathione peroxidase activity was determined according to the previously reported method of Rotruck et al. [30]. Superoxide dismutase activity was determined by the method of Misra and Fridovich [31]. Catalase activity was determined according to the method of Sinha [32]. The ferric-reducing ability of plasma (FRAP) assay was performed according to the method described by Benzie and Strain [33] with slight modification. The FRAP reagent consisted of $300 \mathrm{mM}$ acetate buffer (pH 3.6), $10 \mathrm{mM} \mathrm{TPTZ}$ in $40 \mathrm{mM}$ $\mathrm{HCl}$ and $20 \mathrm{mM} \mathrm{FeCl}_{3} \cdot 6 \mathrm{H}_{2} \mathrm{O}$. A fresh working solution was prepared by mixing $100 \mathrm{~mL}$ of acetate buffer, $10 \mathrm{~mL}$ of TPTZ solution and $10 \mathrm{~mL}$ of $\mathrm{FeCl}_{3} \cdot 6 \mathrm{H}_{2} \mathrm{O}$ solution (10:1:1) and warming was done at $37^{\circ} \mathrm{C}$ before use. For $30 \mathrm{~min}$ in the dark, $0.15 \mathrm{~mL}$ of brain homogenate was allowed to react with $2.8 \mathrm{~mL}$ freshly prepared and pre-warmed $\left(37^{\circ} \mathrm{C}\right)$ FRAP reagent in a test tube. The absorbance of the blue-coloured complex was read against reagent blank (2.8

Neuroprotection by KV in Cerebral

Ischaemia/Reperfusion Injury
$\mathrm{mL}$ FRAP and $0.15 \mathrm{~mL}$ distilled water) at $593 \mathrm{~nm}$. Standard solutions of $\mathrm{Fe}^{2+}$ in the range of $100-1,000 \mathrm{mM}$ were prepared from ferrous sulphate $\left(\mathrm{FeSO}_{4} \cdot 7 \mathrm{H}_{2} \mathrm{O}\right)$ in distilled water.

Determination of Electrolyte Levels

Comparison of levels of $\mathrm{Ca}^{2+}, \mathrm{Na}^{+}, \mathrm{K}^{+}$and $\mathrm{Mg}^{2+}$ among groups was achieved spectrophotometrically, using assay kits obtained from Teco Diagnostics, USA. Calcium reacts with cresolphthalein complexone in 8-hydroxyquinoline to form a purple-coloured complex, which was read at $578 \mathrm{~nm}$. The intensity of the colour is proportional to the calcium concentration. Sodium is precipitated as the triple salt, sodium magnesium uranyl acetate, with the excess uranium then being made to react with ferrocyanide, producing a chromophore whose absorbance, measured at $550 \mathrm{~nm}$, varies inversely as the concentration of sodium in the test specimen. The amount of potassium was determined by using sodium tetraphenylboron in a specifically prepared mixture to produce a colloidal suspension. The turbidity of this suspension, read at $500 \mathrm{~nm}$, is proportional to potassium concentration. Magnesium forms a coloured complex with calmagite in alkaline medium to produce a red complex that is measured spectrophotometrically at $530 \mathrm{~nm}$. Ethylene glycol tetraacetic acid serves to complex calcium and prevents its interference, and a surfactant eliminates the effect of protein. The colour produced is proportional to the magnesium concentration. Estimated electrolyte levels were expressed in $\mathrm{mmol} / \mathrm{mg}$ protein.

\section{Evaluation of Lactate Dehydrogenase Activity}

Lactate Dehydrogenase (LDH) activity was evaluated using assay kit from Randox Laboratory Ltd., UK following the instruction of the manufacturer. One vial of nicotinamide adenine dinucleotide $(\mathrm{NADH})$ was reconstituted with $3 \mathrm{~mL}$ of buffer and substrate to give the reagent used. Test sample $(0.02 \mathrm{~mL})$ was added to $1 \mathrm{~mL}$ of a reagent containing phosphate buffer $(50 \mathrm{mmol} / \mathrm{L}, \mathrm{pH} 7.5)$ and pyruvate $(0.6 \mathrm{mmol} / \mathrm{L})$. After mixture, the initial absorbance was taken after $30 \mathrm{~s}$ and then at 1,2 and 3 min against a water blank at $340 \mathrm{~nm}$. LDH activity was expressed in units/mg protein.

\section{Acetylcholinesterase activity}

Acetylcholinesterase (AChE) activity was measured by the wellreported spectrophotometric method developed by Ellman et al. [34].

\section{Statistical Analysis}

Results were presented as mean \pm SEM. Statistical differences were determined using one-way analysis of variance followed by Duncan's multiple range test using SPSS 16.0 and $p<0.05$ was considered statistically significant.

\section{Results}

\section{Effect of KV on I/R-Induced Neurobehavioural Deficits}

A significant increase in the time taken by animals to start walking was observed in the ischaemia/reperfusion (I/R) group compared with the sham-operated group $(p<$ 0.001 ). Animals in the $\mathrm{I} / \mathrm{R}+\mathrm{KV}$ group (pretreated with $\mathrm{KV}$ before I/R injury) showed significant improvement in time to initiate walking (Fig. 2a). Similarly, there was a signifi- 


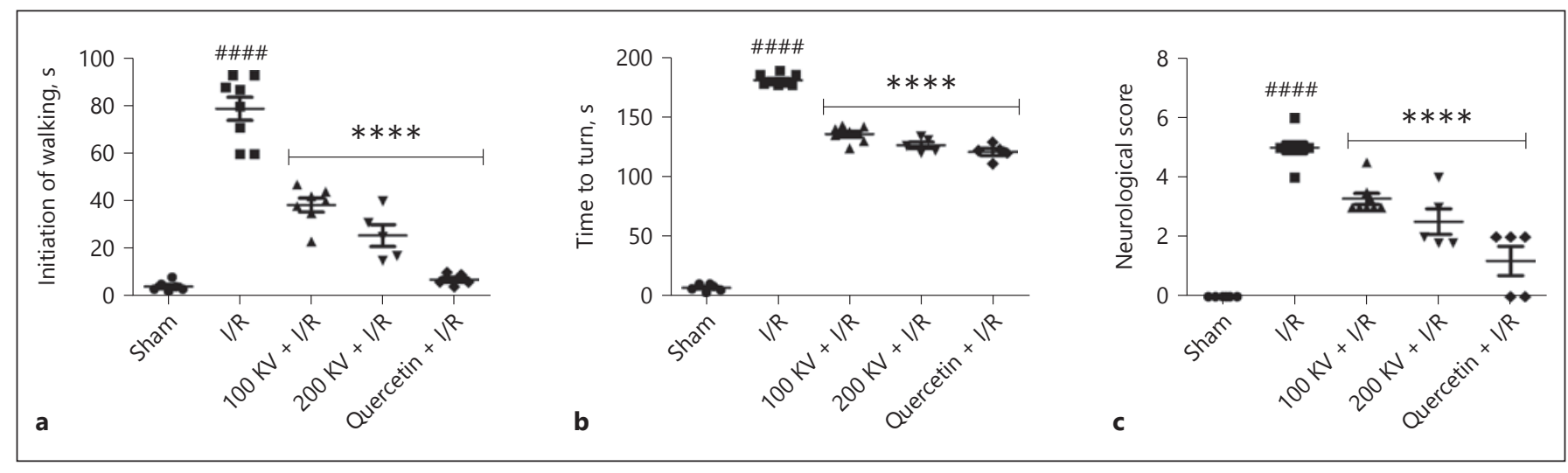

Fig. 2. Neurobehavioural performance of rats following kolaviron $(\mathrm{KV})$ pretreatment and cerebral ischemia/reperfusion (I/R) injury. Results are presented as mean $\pm \operatorname{SEM}(n \geq 5)$. a Time taken for animals to initiate walking (b) time taken for animals to turn in an alley (c) performance of animals in the beam balance test. ${ }^{\# \# \#} p<0.0001$

cant delay $(p<0.001)$ in the time taken by animals in the I/R group to turn around from the impassable end, and face the open end of the alley compared to the sham-operated group. Pretreatment with KV significantly decreased the time taken to turn around (Fig. 2b).In the beambalance test(Fig. 2c), animals in the I/R group displayed lack of motor coordination and balance as compared to the sham group. KV-pretreated animals showed improved motor coordination and balancing on the beam compared with the ischaemia/reperfusion group $(p<0.001)$. The performance of the $200 \mathrm{KV}+$ $\mathrm{I} / \mathrm{R}$ group in the turning in alley test was not different from that of the quercetin $+\mathrm{I} / \mathrm{R}$ group $(p>0.05)$.

\section{Effect of KV on I/R-Induced Disturbance in Redox Homeostasis}

As shown in Figure 3, pretreatment with KV curtailed oxidative stress occasioned by I/R. The decreased GSH level and increased MDA level (Fig. 3a), the reduced activities of the antioxidant enzymes (Fig. 3b-d), and the decreased FRAP value (Fig.3e) in both cortex and striatum were all corrected to varying degrees. In some instances, the protective effect shown by the highest dose of $\mathrm{KV}$ was comparable to that of quercetin.

Fig. 3. Effect of kolaviron (KV) pretreatment on disturbed redox homeostasis after cerebral ischemia/reperfusion (I/R) injury. Results are presented as mean $\pm \operatorname{SEM}(n=6)$. a Reduced glutathione (GSH) and malondialdehyde (MDA) levels of animals (b) Glutathione peroxidase (GPx) activity of animals (c) Superoxide dismutase (SOD) activity of animals (d) Catalase activity of animals (e) Ferric reducing ability of plasma (FRAP) value of animals. ${ }^{* * * *} p<0.0001$ vs. Sham; ${ }^{\# \# \#} p<0.0001$ vs. I/R; ${ }^{\# \# \#} p<0.001$ vs. I/R; ${ }^{\# \#} p<0.01$ vs. vs. Sham; ${ }^{* * * *} p<0.0001$ vs. I/R. Sham: sham-operated animals; I/R: I/R control group; $100 \mathrm{mg} / \mathrm{kg} \mathrm{KV} \mathrm{+} \mathrm{I/R:} \mathrm{group} \mathrm{pretreated} \mathrm{with} 100$ $\mathrm{mg} / \mathrm{kg} \mathrm{KV}$ followed by I/R; $200 \mathrm{mg} / \mathrm{kg} \mathrm{KV} \mathrm{+} \mathrm{I/R:} \mathrm{group} \mathrm{pretreated}$ with $200 \mathrm{mg} / \mathrm{kg} \mathrm{KV}$ followed by I/R; $20 \mathrm{mg} / \mathrm{kg}$ quercetin + I/R: group pretreated with $20 \mathrm{mg} / \mathrm{kg}$ quercetin followed by I/R.

Effect of KV on I/R-Altered Cerebral Electrolyte Levels Increased $\mathrm{Ca}^{2+}$ and $\mathrm{Na}^{+}$levels were observed in the I/R group compared to those of the sham group (Fig. 4a, b). Conversely, $\mathrm{K}^{+}$and $\mathrm{Mg}^{2+}$ levels were decreased in the I/R group (Fig. 4c, d). Pretreatment with $\mathrm{KV}$ and quercetin ameliorated this alteration and restored levels of these ions to near-sham values in some instances.

\section{Effect of KV on LDH Activity following I/R Injury}

There was an increase in the activity of LDH in the I/R group compared to the sham group ( $p<0.0001$; Fig. 5). $\mathrm{KV}$ or quercetin pretreatment significantly mitigated this increase in the activity of LDH.

\section{Effect of KV on AChE Activity following I/R Injury}

AChE activity in all experimental groups is shown in Fig. 6. The significant decrease observed in AChE activity in the $I / R$ group compared to that of the sham group $(p<0.05)$ in both cortex and striatum was ameliorated in KV- and quercetin-pretreated groups.

I/R; \# $p<0.05$ vs. I/R. Sham: sham-operated animals; I/R: I/R control group; $100 \mathrm{mg} / \mathrm{kg} \mathrm{KV} \mathrm{+} \mathrm{I/R:} \mathrm{group} \mathrm{pretreated} \mathrm{with} 100 \mathrm{mg} / \mathrm{kg}$ $\mathrm{KV}$ followed by I/R; $200 \mathrm{mg} / \mathrm{kg} \mathrm{KV}+\mathrm{I} / \mathrm{R}$ : group pretreated with 200 $\mathrm{mg} / \mathrm{kg} \mathrm{KV}$ followed by I/R; $20 \mathrm{mg} / \mathrm{kg}$ quercetin + I/R: group pretreated with $20 \mathrm{mg} / \mathrm{kg}$ quercetin followed by I/R; $100 \mathrm{mg} / \mathrm{kg} \mathrm{KV}$ : group administered $100 \mathrm{mg} / \mathrm{kg} \mathrm{KV}$ without I/R; $200 \mathrm{mg} / \mathrm{kg} \mathrm{KV}$ : group administered $200 \mathrm{mg} / \mathrm{kg} \mathrm{KV}$ without I/R; $20 \mathrm{mg} / \mathrm{kg}$ quercetin: group administered $20 \mathrm{mg} / \mathrm{kg}$ quercetin without I/R.

(For figure 3 see next page.)
Akinmoladun/Saliu/Olowookere/Ojo/ Olaleye/Farombi/Akindahunsi 

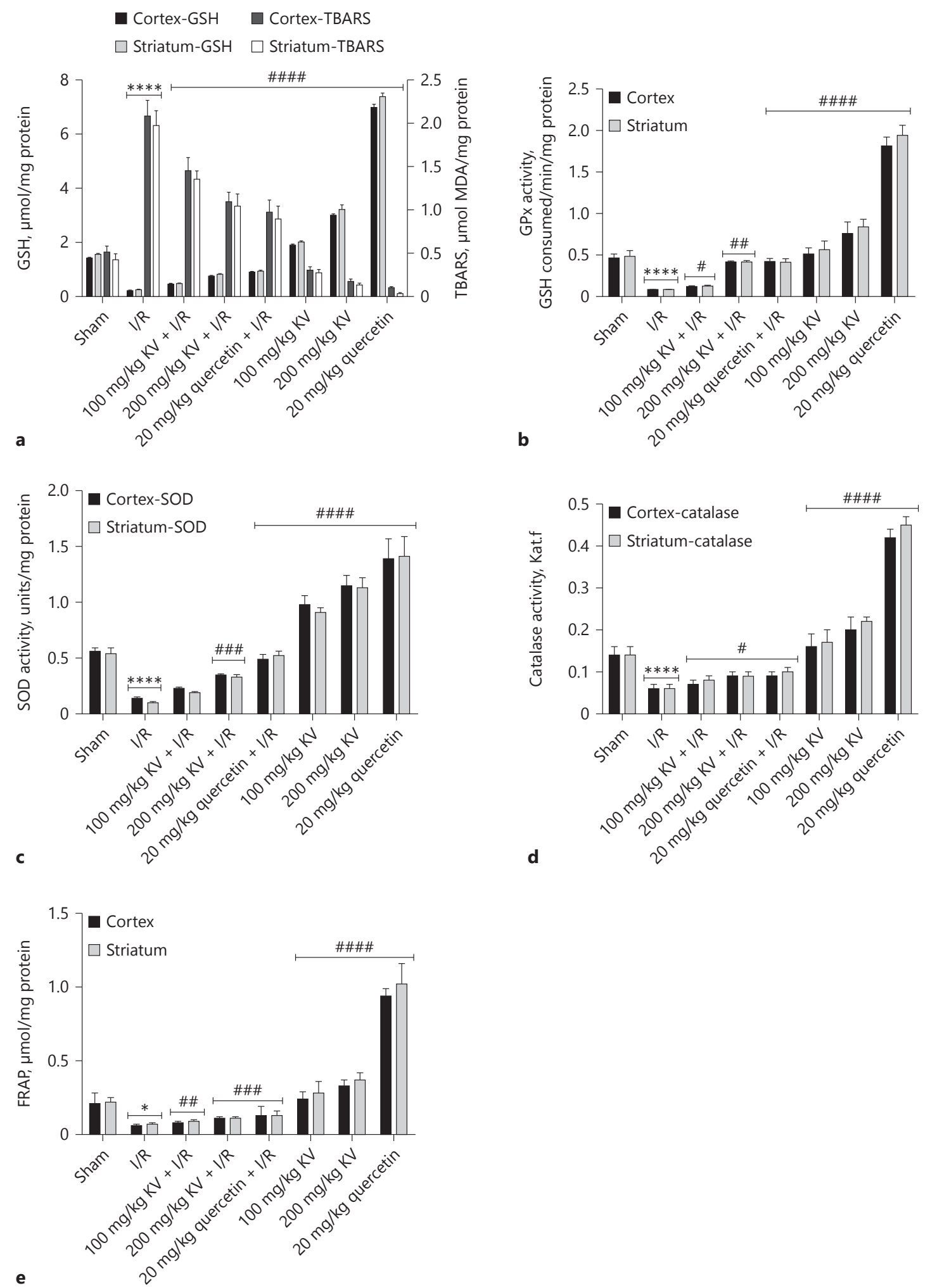

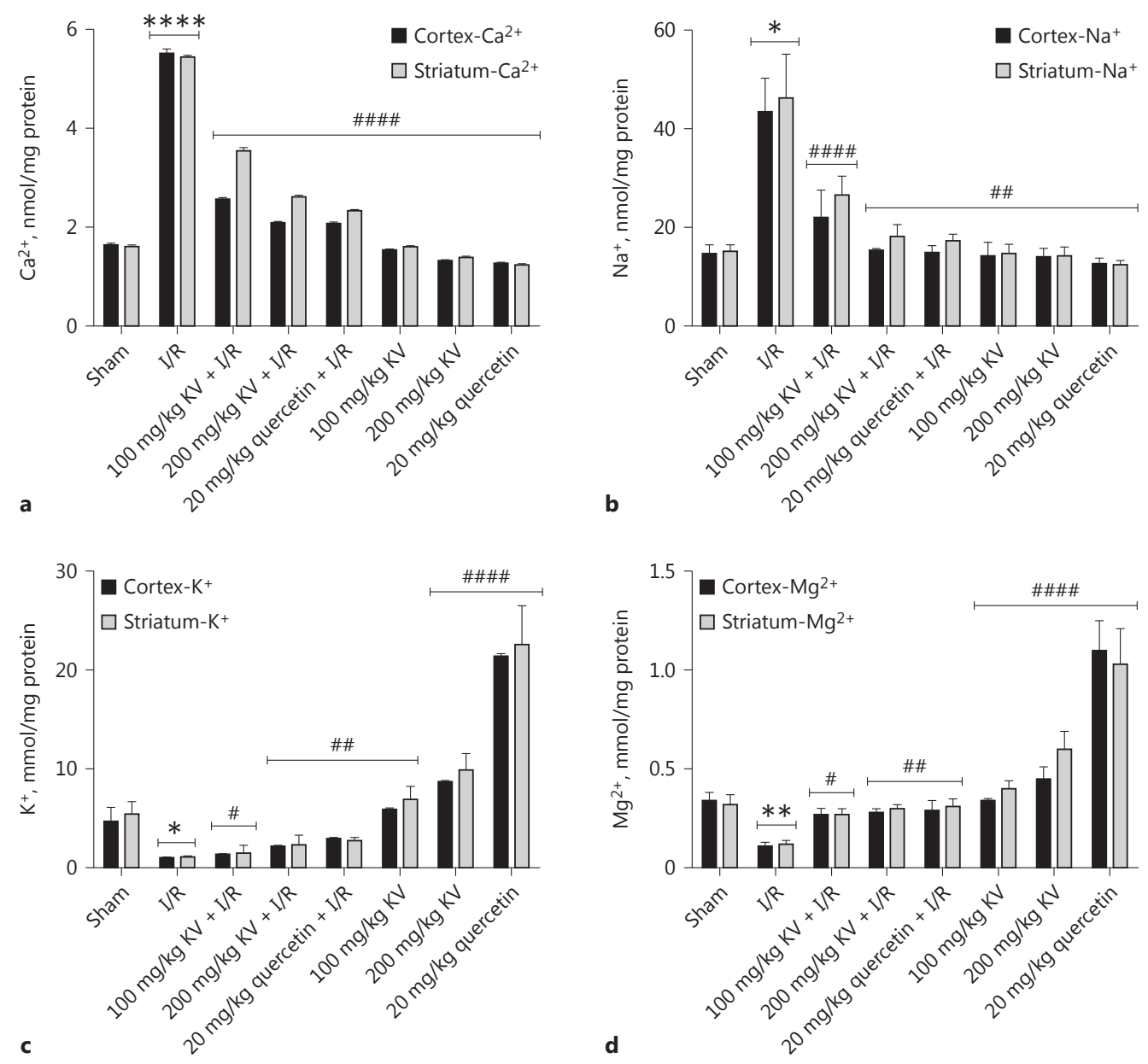

Fig. 4. Ameliorative effect of kolaviron (KV) on cerebral ischemia/ reperfusion (I/R)-induced ionic imbalance in rats. Results are presented as mean \pm SEM $(n=6)$. a Ca ${ }^{2+}$ level in all groups (b) $\mathrm{Na}^{+}$ level in all groups (c) $\mathrm{K}^{+}$level in all groups (d) $\mathrm{Mg}^{2+}$ level in all groups. ${ }^{* * * *} p<0.0001$ vs. Sham; ${ }^{* *} p<0.01$ vs. Sham; ${ }^{*} p<0.05$ vs. Sham; ${ }^{\# \# \# ~} p<0.0001$ versus I/R; ${ }^{\# \#} p<0.01$ vs. I/R; ${ }^{\#} p<0.05$ vs. I/R. Sham: sham-operated animals; I/R: I/R control group; 100

\section{Discussion}

The current study indicates that KV exerted its pharmacological activity through multiple targets, an important factor that influences the therapeutic efficacy of bioactive agents in pathologies like stroke, which have multiple underlying pathophysiological pathways. The ability to interact with multiple targets also enhances the perception of drugs as having the potential for translation to clinical use and contributes to their selection as candidates for drug development.

$\mathrm{mg} / \mathrm{kg} \mathrm{KV}+\mathrm{I} / \mathrm{R}$ : group pretreated with $100 \mathrm{mg} / \mathrm{kg} \mathrm{KV}$ followed by I/R; $200 \mathrm{mg} / \mathrm{kg} \mathrm{KV} \mathrm{+} \mathrm{I/R:} \mathrm{group} \mathrm{pretreated} \mathrm{with} 200 \mathrm{mg} / \mathrm{kg} \mathrm{KV}$ followed by I/R; $20 \mathrm{mg} / \mathrm{kg}$ quercetin $+\mathrm{I} / \mathrm{R}$ : group pretreated with $20 \mathrm{mg} / \mathrm{kg}$ quercetin followed by I/R; $100 \mathrm{mg} / \mathrm{kg} \mathrm{KV}$ : group administered $100 \mathrm{mg} / \mathrm{kg} \mathrm{KV}$ without I/R; $200 \mathrm{mg} / \mathrm{kg} \mathrm{KV}$ : group administered $200 \mathrm{mg} / \mathrm{kg} \mathrm{KV}$ without I/R; $20 \mathrm{mg} / \mathrm{kg}$ quercetin: group administered $20 \mathrm{mg} / \mathrm{kg}$ quercetin without $\mathrm{I} / \mathrm{R}$.

Global ischaemia leads to behavioural consequences, which are seen in tasks that reflect sensorimotor and locomotor functional abilities [35-37]. The amelioration of I/R-induced neurobehavioural deficits by KV could be adduced to the mitigation of neurodegeneration, which implied conservation of the neuron densities of the affected brain regions [10]. This is very important, since apoptotic or necrotic neuron death is a feature of stroke.

The involvement of oxidative stress, ionic imbalance especially perturbations in cationic flux - acidosis, and impairment of cholinergic neurotransmission in the pathophysiology of brain ischaemia/reperfusion injury, which 
Fig. 5. Lactate dehydrogenase activity in kolaviron (KV) pretreated rats subjected to cerebral ischemia/reperfusion (I/R) injury. Results are presented as mean $\pm \operatorname{SEM}(n=$ 6). ${ }^{* * * *} p<0.0001$ vs. Sham; ${ }^{\# \# \# \# ~} p<0.0001$ vs. I/R. Sham: sham-operated animals; I/R: I/R control group; $100 \mathrm{mg} / \mathrm{kg} \mathrm{KV} \mathrm{+} \mathrm{I/R:}$ group pretreated with $100 \mathrm{mg} / \mathrm{kg} \mathrm{KV}$ followed by I/R; 200 mg/kg KV + I/R: group pretreated with $200 \mathrm{mg} / \mathrm{kg} \mathrm{KV}$ followed by I/R; $20 \mathrm{mg} / \mathrm{kg}$ quercetin + I/R: group pretreated with $20 \mathrm{mg} / \mathrm{kg}$ quercetin followed by I/R; $100 \mathrm{mg} / \mathrm{kg} \mathrm{KV}$ : group administered 100 mg/kg KV without I/R; 200 mg/kg KV: group administered $200 \mathrm{mg} / \mathrm{kg} \mathrm{KV}$ without $\mathrm{I} / \mathrm{R} ; 20 \mathrm{mg} / \mathrm{kg}$ quercetin: group administered $20 \mathrm{mg} / \mathrm{kg}$ quercetin without I/R.

Fig. 6. Acetylcholinesterase activity in kolaviron $(\mathrm{KV})$ pretreated rats subjected to cerebral ischemia/reperfusion (I/R) injury. Results are presented as mean $\pm \operatorname{SEM}(n=$ 6). ${ }^{* * * *} p<0.0001$ vs. Sham; ${ }^{\# \# \# \# ~} p<0.0001$ vs. I/R. ${ }^{* * * *} p<0.0001$ vs. Sham; ${ }^{\# \# \# \# ~} p<$ 0.0001 versus I/R. Sham: sham-operated animals; I/R: I/R control group; $100 \mathrm{mg} / \mathrm{kg}$ $\mathrm{KV}+\mathrm{I} / \mathrm{R}$ : group pretreated with $100 \mathrm{mg} / \mathrm{kg}$ KV followed by I/R; $200 \mathrm{mg} / \mathrm{kg} \mathrm{KV} \mathrm{+} \mathrm{I/R:}$ group pretreated with $200 \mathrm{mg} / \mathrm{kg} \mathrm{KV}$ followed by I/R; $20 \mathrm{mg} / \mathrm{kg}$ quercetin $+\mathrm{I} / \mathrm{R}$ : group pretreated with $20 \mathrm{mg} / \mathrm{kg}$ quercetin followed by I/R; $100 \mathrm{mg} / \mathrm{kg} \mathrm{KV}$ : group administered $100 \mathrm{mg} / \mathrm{kg} \mathrm{KV}$ without I/R; 200 $\mathrm{mg} / \mathrm{kg} \mathrm{KV}$ : group administered $200 \mathrm{mg} / \mathrm{kg}$ $\mathrm{KV}$ without I/R; $20 \mathrm{mg} / \mathrm{kg}$ quercetin: group administered $20 \mathrm{mg} / \mathrm{kg}$ quercetin without I/R.
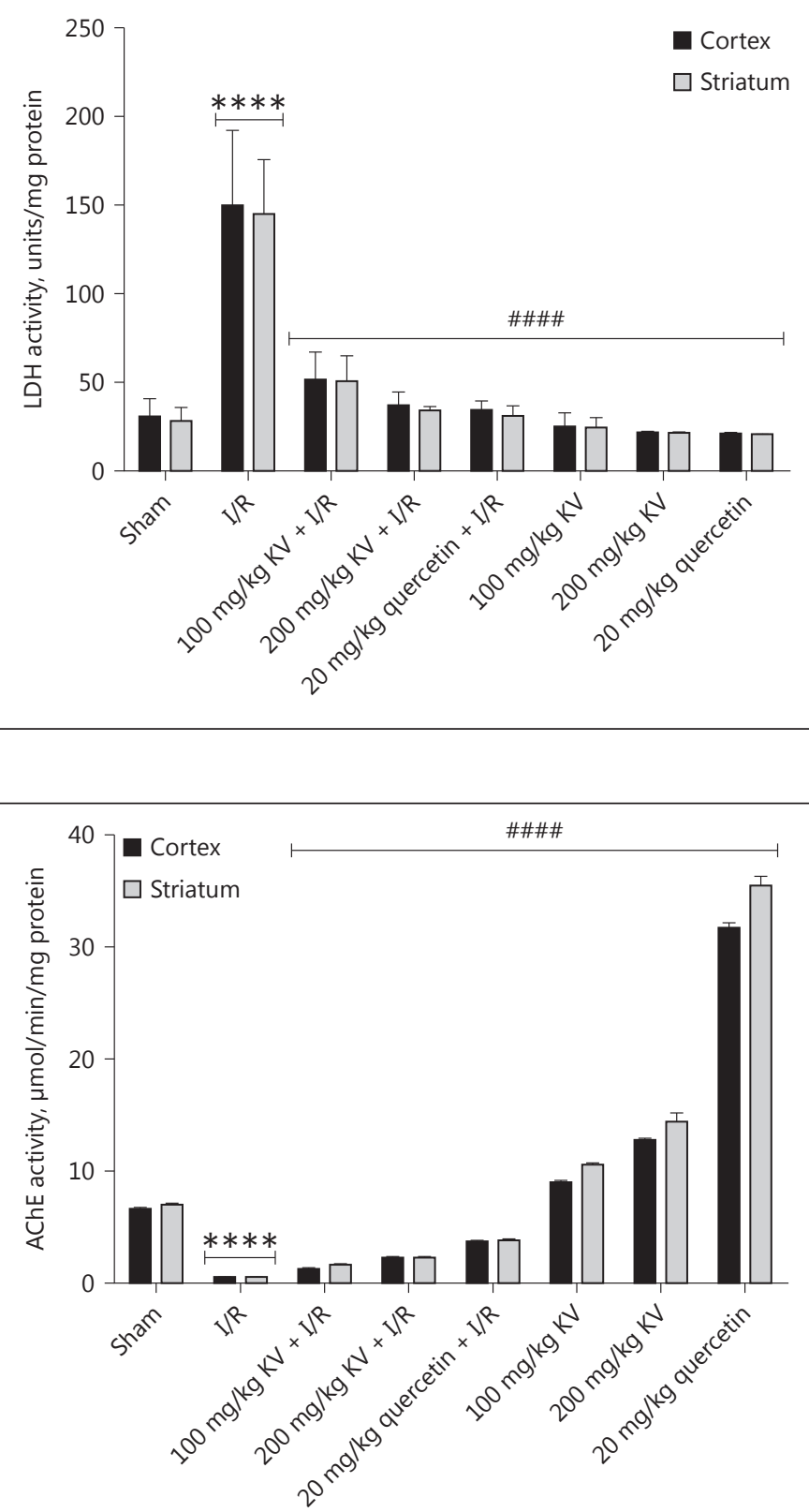

are important biochemical targets for drug development against stroke, is reiterated by findings from the present study $[12,38]$. Thefavourable modulation of these events by $\mathrm{KV}$ correlated with its positive effect on neurobehavioural performance, thereby indicating the potential pharmacological efficacy of the extract for the treatment of stroke.

Oxidative stress has been linked to I/R injury through the impairment of multiple biochemical processes. The primary source of reactive oxygen species during cerebral ischaemia injury is the mitochondria, which generates su- peroxide radical and other radicals during the electron transport process [39-41]. Superoxide dismutase plays a key role in antioxidant defense via the dismutation of superoxide radical and prevention of the generation of the highly damaging hydroxyl radical through iron-catalyzed Haber-Weiss reaction. In addition, glutathione metabolism is a very important antioxidant defense mechanism in cells. Glutathione peroxidase, along with GSH eliminates peroxides as potential substrates for the Fenton reaction. Increasing intracellular GSH was reported as a distinct 
mechanism of protection by flavonoids [22]. Another antioxidant enzyme, catalase, with one of the highest turnover rates for all enzymes, efficiently converts $\mathrm{H}_{2} \mathrm{O}_{2}$ to water and oxygen and contributes to mopping up the reactive oxygen species (ROS). Free radicals promote lipid peroxidation, which results in alteration of the permeability and fluidity of membrane. ROS produce MDA, an end product of lipid peroxidation. Reperfusion after ischaemia increases damage to neuronal cells and tissues through oxidative burst, further contributing to the oxidative stress, which has been implicated in a variety of acute and chronic neurologic conditions; reperfusion also causes cytotoxicity through lipid peroxidation, oxidation of proteins and DNA fragmentation. This oxidation causes further tissue damage and is thought to be an important trigger for apoptosis after ischemic stroke [42-45, 38]. KV pretreatment significantly ameliorated decreased activities of the antioxidant enzymes, reduced FRAP value and increased production of thiobarbituric acid reactive substances, caused by I/R demonstrating the strong antioxidant capacity of $\mathrm{KV}$ and its effectiveness in counteracting oxidative stress.

$I / R$ causes a malfunction of the sodium pump as a result of energy depletion, which leads to a profound loss of $\mathrm{Na}^{+}$ and $\mathrm{K}^{+}$ionic gradients and the depolarization of neurons. Uncontrolled membrane depolarization causes massive $\mathrm{Ca}^{2+}$ influx by impairing several $\mathrm{Ca}^{2+}$ ion exchange system such as $\mathrm{Ca}^{2+}$ voltage-dependent channels, $\mathrm{Na}^{+} / \mathrm{Ca}^{2+}$ exchanger and sarco/endoplasmic reticulum $\mathrm{Ca}^{2+}$-ATPase, which activates proteases, phospholipases, endonucleases and $\mathrm{NO}$ synthetase. In addition, overloading $\mathrm{Ca}^{2+}$ in mitochondria can lead to the opening of mitochondria permeability transition pore, promoting apoptosis through the release of cytochrome $c$ and activation of caspases [42, 4650]. Thus, $\mathrm{Ca}^{2+}$ overload leads to a cascade of events that eventually results in ischemic cell death. On the whole, ischaemia-induced energy failure leads to the depolarization of neurons followed by activation and overstimulation of specific membrane-bound receptors, which dramatically increases intracellular $\mathrm{Ca}^{2+}$ and $\mathrm{Na}^{+}$, while $\mathrm{K}^{+}$is released into the extracellular space of the neuron resulting in cell swelling and ultimately to cell death. $\mathrm{Mg}^{2+}$ regulation is also implicated in I/R injury because it serves as physiological blocker of N-methyl-D-aspartate receptors and $\mathrm{Ca}^{2+}$ channels. Alterations to cation levels in this study reflect these observations, and control of these deleterious alterations in KV pretreated groups suggests that KV may have interfered in the early events of ischemic pathophysiology leading to reduction in intensity of ensuing abnormalities.

$\mathrm{LDH}$ is a key enzyme involved in the anaerobic conversion of pyruvate into lactic acid. During ischaemia, the affected cells become dependent on anaerobic glycolysis for their ATP supply. This leads to an accumulation of lactate and protons and, therefore, a drop in cytosolic $\mathrm{pH}$. Acid build up in brain tissue aggravates brain injury associated with cerebral ischaemia by mechanisms probably involving the activation of acid-sensing ion channels, which are permeable to $\mathrm{Ca}^{2+}$ and $\mathrm{Na}^{+}$and may be involved in neuronal $\mathrm{Ca}^{2+}$ accumulation and injury associated with cerebral ischaemia. Specifically, ASIC1 a activation has been reported to be involved in acidosis-mediated ischemic brain injury $[11,46,48]$. The regulation of cerebral lactic acidosis by KV pretreatment in this study suggests the amelioration of dysregulated bioenergetic metabolism and is another major indicator of its neuroprotective efficacy against $\mathrm{I} / \mathrm{R}$ injury.

The neurotransmitter, acetylcholine, associated with learning and memory is metabolized by the enzyme $\mathrm{AChE}$ to choline and acetyl-CoA. Decrease in the activity of AChE in the I/R group indicated abnormality in synaptic neurotransmission, and mitigation of the decreased activity in KV-pretreated groups supports previous finding that flavonoids modulate critical neuronal signaling pathways [51]. Quercetin, the reference flavonoid employed in this study has been described as a cognitive enhancer [20].

The cortex and striatum are 2 important regions of the brain that are affected by cerebral ischaemia and reperfusion injury. Central nervous system neurons have different vulnerabilities to ischemic insult. The cerebral cortex process sensory information or coordinate motor output necessary for control of movement. Therefore, disturbances in cortical cholinergic system can affect locomotor coordination [52]. The striatum is necessary for voluntary motor control, participates in cognition and reward process and receives inputs from different areas of the cortex [53]. This study showed that KV pretreatment for $1 \mathrm{~h}$ before I/R injury can afford excellent protection against neurological dysfunction in the cortex and striatum. This time lapse fits into the 3-h therapeutic window for thrombolytic stroke therapy. Additionally, the present study showed positive correlation between favourable control of biochemical aberrations and improvement of neurobehavioural deficits.

\section{Conclusion}

The need for a continuous search of cerebral ischaemia damage mechanisms and effective intervention strategies for neuroprotection cannot be over-emphasized. Previous works and the current study indicate that $\mathrm{KV}$ is a multitarget bioactive agent, an important criterion for
Akinmoladun/Saliu/Olowookere/Ojo/ Olaleye/Farombi/Akindahunsi 
therapeutic efficacy in pathologies with underlying multiple pathophysiological pathways. KV significantly mitigated cerebral ischaemia/reperfusion provoked ionic and redox imbalance, lactic acidosis, AChE malfunction and neurobehavioural disorder. It is concluded that KV merits serious consideration and detailed investigation as a candidate for drug development for stroke therapy.

\section{Disclosure Statement}

There is no funding source. Authors declare no conflict of interest. Article complies with ICMJE guidelines.

\section{Ethical Approval}

The study was approved by the departmental Ethical Committee on animal research (ref. No. FUTA/BCH/BPT/2017/003).

\section{Author Contribution}

Experiments were designed and executed by A.C.A., I.O.S., and B.D.O. Laboratory facilities/reagents and materials/analysis tools and other logistics were provided by A.C.A., O.B.O., M.T.O., E.O.F., and A.A.A. Data analysis and manuscript preparation were performed by A.C.A., I.O.S., and B.D.O. All authors approved the final form of the manuscript.

\section{References}

1 Li S, Li S, Liu C, Liu C, Zhang Y: Extraction and isolation of potential anti-stroke compounds from flowers of Pueraria lobata guided by in vitro PC12 cell model. J Chromatogr B Analyt Technol Biomed Life Sci 2017;1048: 111-120.

-2 Ahmad N, Ahmad R, Alam MA, Samim M, Iqbal Z, Ahmad FJ: Quantification and evaluation of thymoquinone loaded mucoadhesive nanoemulsion for treatment of cerebral ischemia. Int J Biol Macromol 2016;88:320-332.

3 Feigin VL, Roth GA, Naghavi M, Parmar P, Krishnamurthi R, Chugh S, et al: Global burden of stroke and risk factors in 188 countries, during 1990-2013: a systematic analysis for the Global Burden of Disease Study 2013. Lancet Neurol 2016;15:913-924.

4 Hachinski V, Azarpazhooh MR: Stroke is a burdensome but preventable brain disorder. Lancet Neurol 2016;15:892-893.

5 Martins AH, Hu J, Xu Z, Mu C, Alvarez P, Ford BD, et al: Neuroprotective activity of (1S,2E,4R,6R,-7E,11E)-2,7,11-cembratriene-4,6-diol (4R) in vitro and in vivo in rodent models of brain ischemia. Neuroscience 2015;291:250-259.

-6 Stary CM, Giffard RG: Advances in astrocytetargeted approaches for stroke therapy: an emerging role for mitochondria and microRNAs. Neurochem Res 2015;40:301-307.

-7 Chehaibi K, Trabelsi I, Mahdouani K, Slimane MN: Correlation of oxidative stress parameters and inflammatory markers in ischemic stroke patients. J Stroke Cerebrovasc Dis 2016;25:2585-2593.

8 Davis SM, Pennypacker KR: Targeting antioxidant enzyme expression as a therapeutic strategy for ischemic stroke. Neurochem Int 2017;107:23-32.

-9 Hoque A, Hossain MI, Ameen SS, Ang CS, Williamson N, Ng DCH, et al: A beacon of hope in stroke therapy-Blockade of pathologically activated cellular events in excitotoxic neuronal death as potential neuroprotective strategies. Pharmacol Ther 2016;160:159-179.
10 Lau A, Tymianski M: Glutamate receptors, neurotoxicity and neurodegeneration. Pflugers Arch 2010;460:525-542.

11 Leng T, Shi Y, Xiong ZG, Sun D: Proton-sensitive cation channels and ion exchangers in ischemic brain injury: new therapeutic targets for stroke? Prog Neurobiol 2014;0:189-209.

12 Nour M, Scalzo F, Liebeskind DS: Ischemiareperfusion injury in stroke. Interv Neurol 2013;1:185-199.

13 Zhang H, Lai Q, Li Y, Liu Y, Yang M: Learning and memory improvement and neuroprotection of Gardenia jasminoides (Fructus gardenia) extract on ischemic brain injury rats. J Ethnopharmacol 2017;196:225-235.

-14 Guo C, Yin Y, Duan J, Zhu Y, Yan J, Wei G, et al: Neuroprotective effect and underlying mechanism of sodium danshensu [3-(3, 4-dihydroxyphenyl) lactic acid from Radix and Rhizoma Salviae miltiorrhizae $=$ Danshen] against cerebral ischemia and reperfusion injury in rats. Phytomedicine 2015;22: 283-289.

15 Wan L, Cheng Y, Luo Z, Guo H, Zhao W, Gu $\mathrm{Q}$, et al: Neuroprotection, learning and memory improvement of a standardized extract from Renshen Shouwu against neuronal injury and vascular dementia in rats with brain ischemia. J Ethnopharmacol 2015;165:118126.

16 Kumar GP, Khanum F: Neuroprotective potential of phytochemicals. Pharmacogn Rev 2012;6:81-90.

-17 Ishola IO, Adamson FM, Adeyemi OO: Ameliorative effect of kolaviron, a biflavonoid complex from Garcinia kola seeds against scopolamine-induced memory impairment in rats: role of antioxidant defense system. Metab Brain Dis 2017;32:235-245.

18 Kalu WO, Okafor PN, Ijeh II, Eleazu C: Effect of kolaviron, a biflavanoid complex from Garcinia kola on some biochemical parameters in experimentally induced benign prostatic hyperplasic rats. Biomed Pharmacother 2016; 83:1436-1443.
19 Milatovic D, Zaja-Milatovic S, Gupta RC: Chapter 29 - Oxidative Stress and Excitotoxicity: Antioxidants from Nutraceuticals: $\mathrm{Nu}-$ traceuticals. Boston, Academic Press, 2016, pp 401-413.

20 Suganthy N, Devi KP, Nabavi SF, Braidy N, Nabavi SM: Bioactive effects of quercetin in the central nervous system: focusing on the mechanisms of actions. Biomed Pharmacother 2016;84:892-908.

21 Sunil AG, Kesavanarayanan KS, Kalaivani P, Sathiya S, Ranju V, Priya RJ, et al: Total oligomeric flavonoids of Cyperus rotundus ameliorates neurological deficits, excitotoxicity and behavioral alterations induced by cerebral ischemic-reperfusion injury in rats. Brain Res Bull 2011;84:394-405.

22 Ishige K, Schubert D, Sagara Y: Flavonoids protect neuronal cells from oxidative stress by three distinct mechanisms. Free Radic Biol Med 2001;30:433-446.

23 Ijomone OM, Obi AU: Kolaviron, isolated from Garcinia kola, inhibits acetylcholinesterase activities in the hippocampus and striatum of wistar rats. Ann Neurosci 2013;20:4246.

24 Igado OO, Olopade JO, Adesida A, Aina OO, Farombi EO: Morphological and biochemical investigation into the possible neuroprotective effects of kolaviron (Garcinia kola bioflavonoid) on the brains of rats exposed to vanadium. Drug Chem Toxicol 2012;35:371380 .

25 Akinmoladun AC, Akinrinola BL, Olaleye MT, Farombi EO: Kolaviron, a garcinia kola biflavonoid complex, protects against ischemia/reperfusion injury: pertinent mechanistic insights from biochemical and physical evaluations in rat brain. Neurochem Res 2015;40:777-787.

26 Farbiszewski R, Bielawski K, Bielawska A, Sobaniec W: Spermine protects in vivo the antioxidant enzymes in transiently hypoperfused rat brain. Acta Neurobiol Exp (Warsz) 1995; 55:253-258. 
27 Alexis NE, Dietrich WD, Green EJ, Prado R, Watson BD: Nonocclusive common carotid artery thrombosis in the rat results in reversible sensorimotor and cognitive behavioral deficits. Stroke 1995;26:2338-2346.

28 Beutler E, Duron O, Kelly BM: Improved method for the determination of blood glutathione. J Lab Clin Med 1963;61:882-888.

-29 Ohkawa H, Ohishi N, Yagi K: Assay for lipid peroxides in animal tissues by thiobarbituric acid reaction. Anal Biochem 1979;95:351-358.

30 Rotruck JT, Pope AL, Ganther HE, Swanson AB, Hafeman DG, Hoekstra WG: Selenium: biochemical role as a component of glutathione peroxidase. Science 1973;179:588-590.

-31 Misra HP, Fridovich I: The role of superoxide anion in the autoxidation of epinephrine and a simple assay for superoxide dismutase. J Biol Chem 1972;247:3170-3175.

- 32 Sinha AK: Colorimetric assay of catalase. Anal Biochem 1972;47:389-394.

-33 Benzie IF, Strain JJ: The ferric reducing ability of plasma (FRAP) as a measure of 'antioxidant power': the FRAP assay. Anal Biochem 1996;239:70-76.

-34 Ellman GL, Courtney KD, Andres V, FeatherStone RM: A new and rapid colorimetric determination of acetylcholinesterase activity. Biochem Pharmacol 1961;7:88-95.

- 35 Wang W, Liu L, Jiang P, Chen C, Zhang T: Levodopa improves learning and memory ability on global cerebral ischemia-reperfusion injured rats in the Morris water maze test. Neurosci Lett 2017;636:233-240.

- 36 Pei B, Yang M, Qi X, Shen X, Chen X, Zhang F: Quercetin ameliorates ischemia/reperfusion-induced cognitive deficits by inhibiting
ASK1/JNK3/caspase-3 by enhancing the Akt signaling pathway. Biochem Biophys Res Commun 2016;478:199-205.

37 Silva BC, de Miranda AS, Rodrigues FG, Silveira ALM, Resende GH de S, Moraes MFD, et al: The 5-lipoxygenase (5-LOX) inhibitor zileuton reduces inflammation and infarct size with improvement in neurological outcome following cerebral ischemia. Curr Neurovasc Res 2015;12:398-403.

38 Schaller B, Graf R: Cerebral ischemia and reperfusion: the pathophysiologic concept as a basis for clinical therapy. J Cereb Blood Flow Metab 2004;24:351-371.

39 Zeng X, Wang H, Xing X, Wang Q, Li W: Dexmedetomidine protects against transient global cerebral ischemia/reperfusion induced oxidative stress and inflammation in diabetic rats. PloS One 2016;11:e0151620.

40 Mansoorali KP, Prakash T, Kotresha D, Prabhu K, Rama Rao N: Cerebroprotective effect of Eclipta alba against global model of cerebral ischemia induced oxidative stress in rats. Phytomedicine Int J Phytother Phytopharm 2012;19:1108-1116.

41 Allen CL, Bayraktutan U: Oxidative stress and its role in the pathogenesis of ischaemic stroke. Int J Stroke Off J Int Stroke Soc 2009; 4:461-470.

42 Sanderson TH, Reynolds CA, Kumar R, Przyklenk K, Hüttemann M: Molecular mechanisms of ischemia-reperfusion injury in brain: pivotal role of the mitochondrial membrane potential in reactive oxygen species generation. Mol Neurobiol 2013;47:9-23.

43 Kvietys PR, Granger DN: Role of reactive oxygen and nitrogen species in the vascular re- sponses to inflammation. Free Radic Biol Med 2012;52:556-592.

44 Im JY, Kim D, Paik SG, Han PL: Cyclooxygenase-2-dependent neuronal death proceeds via superoxide anion generation. Free Radic Biol Med 2006;41:960-972.

45 Crack PJ, Taylor JM: Reactive oxygen species and the modulation of stroke. Free Radic Biol Med 2005;38:1433-1444.

46 Kalogeris T, Baines CP, Krenz M, Korthuis RJ: Cell biology of ischemia/reperfusion injury. Int Rev Cell Mol Biol 2012;298:229-317.

47 Webster KA: Mitochondrial membrane permeabilization and cell death during myocardial infarction: roles of calcium and reactive oxygen species. Future Cardiol 2012;8:863884 .

48 Xiong ZG, Xu TL: The role of ASICS in cerebral ischemia. Wiley Interdiscip Rev Membr Transp Signal 2012;1:655-662.

49 Lemasters JJ, Theruvath TP, Zhong Z, Nieminen A-L: Mitochondrial calcium and the permeability transition in cell death. Biochem Biophys Acta 2009;1787:1395-1401.

50 MacDonald JF, Xiong ZG, Jackson MF: Paradox of $\mathrm{Ca} 2+$ signaling, cell death and stroke. Trends Neurosci 2006;29:75-81.

51 Spencer JP: The interactions of flavonoids within neuronal signalling pathways. Genes Nutr 2007;2:257-273.

52 Chinthu R, Anju TR, Paulose CS: Cholinergic receptor alterations in the cerebral cortex of spinal cord injured rat. Biochem Biophys Rep 2017;10:46-51.

53 Báez-Mendoza R, Schultz W: The role of the striatum in social behavior. Front Neurosci 2013;7:233. 